\title{
Effect of diet, bedding material and ambient temperature on the production of volatile fatty acids and ammonia in the bedding of beef steers in an arctic production system
}

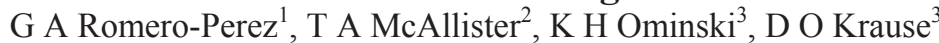

${ }^{1}$ Hokkaido University, Sapporo, Hokkaido, Japan, ${ }^{2}$ Agriculture and Agri-Food Canada Research Centre, Lethbridge, Alberta, Canada, ${ }^{3}$ University of Manitoba, Winnipeg, Manitoba, Canada

Email: gromprz@hotmail.com

Introduction Faecal shedding in modern cattle production is often identified as an important source of microbial contamination of the environment. Moreover, microbes accumulated in the pen bedding can lead to the production of undesirable gas emissions, including volatile fatty acids (VFA) (Miller, 2001) and ammonia. Condensed tannin incubated in vitro with rumen liquor has been shown to lower ammonia concentration and suppress methane formation (Khiaosa-Ard et al., 2009). Bacterial death may occur during freezing due to metabolic injury (Straka and Stokes, 1959). Utilising antimicrobial forages in the diet and/or the bedding of cattle raised in subzero temperatures may inhibit the bacterial growth thereby decreasing gas emissions from bedding. This work examined the impact of the use of sainfoin (Onobrychis viciifolia) in the diet and bedding of beef cattle on VFA concentrations in the bedding pack.

Materials and methods Forty beef steers were allocated by live weight into four pens with either sainfoin or straw as bedding and given water and alfalfa silage or sainfoin silage as $100 \%$ ad libitum diets. Rumen liquor was oral-probe aspirated and faeces grabbed by hand from individual animals. At individual pens several bedding samples were dug out at random by an ice auger, mixed in a bucket and a subsample taken per pen. All samples were collected once in the first three weeks and fortnightly afterwards for seven weeks, and stored in a $-20^{\circ} \mathrm{C}$ freezer. Weekly temperature was averaged from daily ambient temperature (range: -4.6 to $-30.0^{\circ} \mathrm{C}$ ). Frozen rumen liquor and bedding samples were processed as described by Bhandari et al. (2007). Volatile fatty acids (VFA) concentrations were analysed by gas chromatograph (GC) as described by Bhandari et al. (2007) (GC conditions: Injector and detector temperature: $200^{\circ} \mathrm{C}$; initial column temperature: $175^{\circ} \mathrm{C} / 20 \mathrm{~min}$; final column temperature: $200^{\circ} \mathrm{C}$ ). Sample ammonia nitrogen concentration was determined as described by Bhandari et al. (2007). Ammonia and VFA concentrations were analysed by Linear Mixed Models (GenStat, 2007). The fixed model (with each value treated as a distinct factor level) was bedding type * diet * ambient temperature and the random model was week $\times$ pen, with two- and three-way interactions. Significance levels $(\mathrm{P}<0.05, \mathrm{P}<0.01$ and $\mathrm{P}<0.001)$ and standard errors of the means were tested using the Wald test.

Results Results are shown in Table 1. Feeding sainfoin silage and flooring pens with straw lowered the concentration of VFA in the bedding of steers. Diet had very little effect on VFA concentrations in the bedding of animals, but decreased the ammonia concentration in the bedding of steers fed on sainfoin silage. Except for isovaleric acid, ambient temperature and the bedding type $\times$ ambient temperature interaction had a greater effect on VFA concentration in the bedding samples of steers fed on sainfoin silage and with straw bedding than on those fed on alfalfa silage and with sainfoin bedding.

Table 1 Effect of diet, bedding type and ambient temperature on volatile fatty acids and ammonia concentrations in bedding $(\mathrm{mmol} / \mathrm{l})$

\begin{tabular}{|c|c|c|c|c|c|c|c|c|c|}
\hline & & & & & \multirow[t]{3}{*}{ s.e. } & \multicolumn{4}{|c|}{ Significance level } \\
\hline & \multicolumn{2}{|c|}{ Sainfoin bedding } & \multicolumn{2}{|c|}{ Straw bedding } & & \multirow[b]{2}{*}{$\begin{array}{l}\text { Bedding } \\
\text { type }\end{array}$} & \multirow[b]{2}{*}{ Diet } & \multirow[b]{2}{*}{$\begin{array}{l}\text { Amb. } \\
\text { temp. }\end{array}$} & \multirow{2}{*}{$\begin{array}{l}\text { Bedding } \\
\times \text { Amb. } \\
\text { temp. }\end{array}$} \\
\hline & $\begin{array}{l}\text { Alfalfa } \\
\text { silage }\end{array}$ & $\begin{array}{l}\text { Sainfoin } \\
\text { silage }\end{array}$ & $\begin{array}{l}\text { Alfalfa } \\
\text { silage }\end{array}$ & $\begin{array}{l}\text { Sainfoin } \\
\text { silage }\end{array}$ & & & & & \\
\hline Acetic & 3.48 & 2.57 & 1.37 & 1.41 & 0.444 & $* * *$ & n.s. & n.s & * \\
\hline Butyric & 0.18 & 0.09 & 0.01 & 0.01 & 0.031 & $* * *$ & n.s. & $* * *$ & $* * *$ \\
\hline Propionic & 0.32 & 0.17 & 0.08 & 0.10 & 0.053 & $* *$ & n.s. & $* * *$ & * \\
\hline Isobutyric & 0.05 & 0.02 & 0.01 & 0.01 & 0.006 & *** & * & $* *$ & * \\
\hline Isovaleric & 0.02 & 0.02 & 0.01 & 0.01 & 0.006 & * & n.s. & * & n.s. \\
\hline Ammonia & 14.01 & 8.14 & 13.23 & 9.89 & 1.120 & n.s. & $* * *$ & n.s & n.s. \\
\hline
\end{tabular}

Statistical significance $=* \mathrm{P}<0.05 ; * * \mathrm{P}<0.01 ; * * * \mathrm{P}<0.001 ;$ n.s. $=$ not significant. Amb. temp. $=$ ambient temperature.

Conclusions The results showed that feeding sainfoin was effective in lowering the ammonia concentration in the bedding of steers but had little effect on VFA concentrations, partly agreeing with the findings by Khiaosa-Ard et al. (2009). Ambient temperature had a strong effect on VFA concentrations in samples, specially isobutyric, butyric and propionic acids. Interestingly, the concentration of VFA increased when pens were floored with sainfoin. It is not clear the reason for this, but it may be that organisms residing in the bedding were more tolerant to tannins from sainfoin (Khiaosa-Ard et al., 2009) and even thrived in cold temperature possibly with sainfoin as growth medium (Straka and Stokes, 1959). Alternative plant compounds should be tested as bedding material to try to reduce the deleterious effects of modern cattle production such as undesirable gas emissions (Miller, 2001).

Acknowledgements The authors would like to thank Agriculture and Agri-Food Canada for the research funding.

\section{References}

Bhandari, SK, Ominski, KH, Wittenberg, KM and Plaizier, JC. 2007. Journal of Dairy Science 90, 2355-2366

Khiosa-Ard, R, Bryner, SF, Scheeder, MRL, Wettstein, HR, Leiber, F, Kreuzer, M and Soliva, CR. 2009. Journal of Dairy

Science 92, 177-188

Miller, DN. 2001. Journal of Animal Science 79, 2503-2512

Straka, RP and Stokes, JL. 1959. Journal Bacteriology. 78, 181-185 